under "Epithelial Degenerations," at present I cannot affirm its level with certainty, for this reason; the condition is visible only by retro-illumination and not by direct illumination (and therefore not in the optical section). By retro-illumination, it is on one uniform plane stereoscopically well deep to the surface of the epithelium (as located by any adventitious object such as a tear-bubble) to an extent that suggests a level at the surface of Bowman's membrane; but until a case presents itself having a chance additional feature stereoscopically in the same plane by retro-illumination and also visible in the direct illumination of the optical section, it is not possible to determine clinically the exact level of this entity. When, and not before, some such chance has presented itself, I shall publish as full an account as I can of this interesting condition. I would like to add here that I used the word "vacuolation" only provisionally, on the ground that the faint elements composing this feature have the refractile property of "unreversed illumination" (see bottom of p. 447) ; but their visibility is less than that of the ordinary intraepithelial vacuole-perhaps because their shape is different, or perhaps because the difference between their refractive index and that of the surrounding tissue is less -and it might prove eventually that their pathology is different from that of the common vacuole. I have clinical evidence suggestive of the condition being a neuropathic one.

My object in asking if you will kindly insert this comment is that I desire to obviate misinterpretation resulting from tentative presentation within the short space permissible in a text-book.

Yours truly,

Basil GRaves.

LONDON,

January 15, 1937.

\title{
OBITUARY
}

\section{A. HUGH THOMPSON}

WE much regret to announce the death of Dr. Arthur Hugh Thompson. He was born in Cardiff in 1859, and went up to Trinity College, Cambridge, with a scholarship. At this time he showed no particular interest towards the medical profession and he graduated in arts and spent some years in coaching and lecturing. On coming to London he worked at Toynbee Hall for some years, during which time his thoughts turned towards medicine. Thompson was a student at the London Hospital and took the M.R.C.S. in 1891. In the same year he took the M.B.Cantab. and later proceeded to the M.D. After a period of residence at "the London" he began 
work at Moorfields in the clinic of Mr. William Lang, whose chief clinical assistant he became before he was elected to the staff of the Western Ophthalmic Hospital.

Thompson joined the Ophthalmological Society of the United Kingdom in 1895 and served for a period on the council. He was also a Vice-President of the section of ophthalmology of the Royal Society of Medicine. His general training stood him in good stead when he was chosen sub-editor of the Ophthalmic Review in the late nineties. He worked assiduously with Mr. J. B. Lawford and together they steered the journal through a rather critical time. He kept up his interest in "the Review" until it was amalgamated with the others in our columns.

Thompson was also responsible for the ophthalmic section of the Medical Annual for 12 years. Apart from routine editorial writing he was the author of several useful papers, notably one on the late results of the operative treatment of high myopia. He was an excellent clinician, especially in medical cases. His interest in his hospital and his work there was untiring and the present position of the Western Ophthalmic Hospital is largely the result of his years of quiet unostentatious work.

In appearance Hugh Thompson changed singularly little during the past 30 years. Concealing his height by a slight stoop and looking over the top of his reading glasses he always gave one the impression of being reserved and maintaining a detached outlook on life and people. When one got to know him one appreciated how much warmth of character underlay his apparent reticence. $\mathrm{He}$ would take endless pains to help any who genuinely approached him; and his knowledge of foreign languages coupled with a great command of his own, made his writings always of value. Much sympathy will be felt for his widow in her bereavement.

\section{CLARENCE KING}

The American Journal of Ophthalmology (January, 1937) gives an obituary notice of Dr. King who was tragically drowned at Bermuda on August 15, 1936. From it we make the following abstract.

Clarence King was born in 1877 in Newport, Kentucky, and graduated from the Medical College of Ohio in 1901. He put in post-graduate work under Ernst Fuchs in Vienna and later in Berlin. He started practice in ophthalmology in Cincinnati, but went to India in 1912 to work under Col. Henry Smith. Dr. King served in France during the war as Major A.M.S., first at a Base Hospital and later as consulting ophthalmologist in the Allery Area, in Coblenz.

He was surgeon at the Cincinnati General Hospital and Director of the ophthalmic clinic at the Children's Hospital. After having 